Sains Malaysiana 47(1)(2018): 109-115

http://dx.doi.org/10.17576/jsm-2018-4701-13

\title{
Production of Biodiesel from Palm Fatty Acid Distillate by Microwave-Assisted Sulfonated Glucose Acid Catalyst
}

(Penghasilan Biodiesel daripada Sulingan Asid Kelapa Sawit Menggunakan Pemangkin Asid Glukosa Bersulfonat Secara Ketuhar Gelombang Mikro)

\author{
Nur NAZLina SAIMON, Heng KHUAN EU, ANWAR JOHARI, NORZITA NGADI, \\ MAZURA JUSOH \& ZAKI YAMANI ZAKARIA*
}

\begin{abstract}
Biodiesel, one of the renewable energy sources has gained attention for decades as the alternative fuel due to its remarkable properties. However, there are several drawbacks from the industrial production of biodiesel such as the spike in the production cost, environmental issues related to the usage of homogeneous catalyst and profitability in long term. One of the solutions to eliminate the problem is by utilizing low cost starting material such as palm fatty acid distillate (PFAD). PFAD is a byproduct from the refining of crude palm oil and abundantly available. Esterification of PFAD to biodiesel will be much easier with the presence of heterogeneous acid catalyst. Most of acid catalyst preparation involves series of heating process using conventional method. In this study, microwave was utilized in catalyst preparation, significantly reducing the reaction time from conventional heating method. The catalyst produced was characterized using X-Ray Diffraction (XRD), Brunauer Emmet and Teller (BET), Scanning Electron Microscopy (SEM), Temperature-Programmed Desorption - Ammonia (TPD-NH $\mathrm{N}_{3}$ and Fourier Transform Infrared (FTIR) while percentage yield and conversion of the PFAD were analysed by gas chromatography - flame ionization detector (GC-FID) and acid-base titration, respectively. It has been demonstrated that the percentage yield of biodiesel from the PFAD by employing sulfonated glucose acid catalyst $(S G A C)$ reached $98.23 \%$ under the following conditions: molar ratio of methanol to PFAD of 10:1, catalyst loading of $2.5 \%$ and reaction temperature of $70^{\circ} \mathrm{C}$. The microwave-assisted SGAC showed its potential to replace the SGAC produced via conventional heating method.
\end{abstract}

Keywords: Biodiesel; microwave-assisted; PFAD; sulfonated glucose acid catalyst

ABSTRAK

Biodiesel, salah satu daripada sumber tenaga boleh diperbaharui telah mendapat perhatian selama beberapa dekad ini sebagai bahan bakar alternatif kerana sifat luar biasanya. Walau bagaimanapun, terdapat beberapa halangan yang dihadapi oleh industri penghasilan biodiesel seperti kenaikan dalam kos pengeluaran, isu alam sekitar yang berkaitan dengan penggunaan pemangkin homogen serta keuntungan dalam jangka masa panjang. Untuk menyelesaikan isu kos pengeluaran adalah melalui peng gunaan bahan mentah kos rendah seperti sulingan asid lemak sawit (PFAD). PFAD adalah hasil sampingan bernilai rendah daripada penapisan minyak sawit mentah dan terhasil dalam kuantiti yang banyak. Esterifikasi PFAD kepada biodiesel menjadi lebih mudah dengan kehadiran pemangkin asid heterogen. Kebanyakan cara penyediaan pemangkin berasid melibatkan beberapa siri pemanasan menggunakan kaedah konvensional. Ketuhar gelombang mikro digunakan dalam penyediaan pemangkin supaya dapat mengurangkan masa reaksi daripada kaedah pemanasan konvensional. Pemangkin yang dihasilkan dicirikan menggunakan pembelauan sinar X (XRD), Brunauer Emmet dan Teller (BET), mikroskopi elektron imbasan (SEM), program suhu penyahserapan - ammonia (TPD-NH $\left.{ }_{3}\right)$ dan transformasi Fourier Inframerah (FTIR) manakala peratus keputusan dan penukaran PFAD masing-masing telah dianalisis oleh gas kromatografi - nyalaan pengesan pengionan (GC-FID) dan penitratan asid-alkali. Hasil kajian menunjukkan bahawa hasil peratusan biodiesel daripada PFAD dengan menggunakan pemangkin asid glukosa bersulfonat (SGAC) mencapai $98.23 \%$ di bawah kondisi berikut: Nisbah molar metanol : PFAD is 10: 1, penggunaan pemangkin sebanyak $2.5 \%$ bt.dan suhu tindak balas $70^{\circ} \mathrm{C}$. SGAC yang dihasilkan melalui pemanasan ketuhar gelombang mikro menunjukkan potensi untuk menggantikan SGAC yang dihasilkan melalui kaedah pemanasan konvensional.

Kata kunci: Bantuan ketuhar gelombang mikro; biodiesel; pemangkin asid glukosa bersulfonat; PFAD

\section{INTRODUCTION}

Biodiesel or scientifically known as Fatty Acid Methyl Ester (FAME) is a derivation of vegetable oils or even animal fats via a process called esterification. This process involves a chemical reaction between a triglyceride and alcohol with the presence of catalyst. However, several issues have been highlighted among researchers and environmentalist on the high dependency of non-renewable fossil fuels for energy 
production. Liquid bio energy production from vegetable oils has been proposed as one of the possible options to reduce GHG emissions (Achten et al.2008). This is because biodiesel has similar combustion properties as petroleum diesel except it is sulphur-free, making it a cleaner burning fuel than petroleum diesel (Helwani et al. 2009). The most common starting materials to synthesizes biodiesel from vegetable oils are soybean oils, Jatropha oil, palm oil and sunflower oil (Lokman et al. 2015).

In this study, the focus was towards biodiesel production by using PFAD. In 2007, palm oil supplied around $25 \%$ of the global oils and fats despite the fact that its plantation area is less than $5 \%$ of the world agriculture land (Lam \& Lee 2011). Palm oil can give high yield of edible oil with minimum land requirement. The feedstock that has gained attention is PFAD which is a low value by-product from crude palm oil refining. In Malaysia, around 750,000 tonnes of PFAD has been produced every year as a by-product in the crude palm oil refinery process (Malaysian Palm Oil Board 2009). At room temperature, it appears as yellow solid and turns light brown in colour when it melts. Instead of disposing the by-product as a waste, it will be more convenient to convert the PFAD into biodiesel thus, the production cost of biodiesel can be reduced and the environment can be preserved as well. PFAD feedstock consists of high free fatty acid (FFA) content as high as $93 \mathrm{wt}$ \% of FFA. The FFA consists of palmitic, oleic, linoleic, stearic and myristic composition (Chongkhong et al.2007). The high relativeness of the FFA content makes it difficult to be esterified directly, thus the PFAD is required to undergo a two-step process of biodiesel production. The first step is through esterification with sulfuric acid $\left(\mathrm{H}_{2} \mathrm{SO}_{4}\right)$ that can reduce the FFA content in the oil, whereas the second step is the transesterification process using a strong base that converts triglyceride to methyl ester and glycerol in the presence of methanol. Currently, basic homogeneous catalysts used for transesterification include potassium hydroxide $(\mathrm{KOH})$ and sodium hydroxide $(\mathrm{NaOH})$ which can cause environmental issues especially during the wastewater treatment (Di Serio et al. 2007). Apart from that, using PFAD as starting material will encounter difficulties when reacted with homogeneous base catalyst thus, creating a saponification problem later on (Shu et al. 2009).

The use of heterogeneous acid catalyst can solve the problems above. To become an ideal and effective catalyst, the heterogeneous solid acid catalyst must have numerous active sites with high acidity properties and good stability. They must also exhibit great stability, reusability and can be easily separated at the end of the reaction (Atadashi et al. 2012). However, normal preparation of catalysts nowadays involves a series of conventional heating which takes a longer time and energy. Recently, the production of biodiesel has been flooded with various technologies including the utilization of microwave during esterification process but not for preparation of the catalyst. In this study, the catalyst was prepared via microwave-assisted heating method instead of conventional heating. In fact, we can minimize the time consumption starting from the beginning of the process.

This research was focused on the synthesis, characterization and testing of the microwave-assisted sulfonated glucose acid catalyst (SGAC) in esterification of biodiesel. There are three stages of this research including preparation, characterization and catalytic testing of the catalyst. Thus, the aim of this study is to develop microwave assisted sulfonated glucose catalyst for the conversion of PFAD to biodiesel.

\section{MATERIALS AND METHODS}

\section{CHEMICAL AND MATERIALS}

To carry out esterification process to produce biodiesel, PFAD and methanol were used as the reactant meanwhile D-(+) Glucose was modified to be the heterogeneous acid catalyst. PFAD was obtained from Mewaholeo Industries Sdn Bhd. Methanol was purchased from Merck chemical company meanwhile D-(+)glucose was purchased from Qrec (Asia) Sdn. Bhd. $\mathrm{H}_{2} \mathrm{SO}_{4}$ and phenolphthalein $\left(\mathrm{C}_{20} \mathrm{H}_{14} \mathrm{O}_{4}\right)$ were obtained from J.T. Baker, US. The standard methyl esters for GC analysis such as methyl palmitate, methyl oleate, methyl stearate, methyl linoleate and methyl myristate were purchased from Sigma-Aldrich chemical company.

\section{CATALYST PREPARATION}

A series of process is involved in the catalyst preparation such as heating, milling, treatment with $\mathrm{H}_{2} \mathrm{SO}_{4}$, dilution, washing and filtering process. Approximately $20 \mathrm{~g}$ of D-(+) Glucose powder was weighed and heated for $15 \mathrm{~min}$ in a microwave (Brand Sharp R213CST) to produce incomplete carbonized glucose (ICG). The ICG was then milled into powder form. $8 \mathrm{~g}$ of ICG powder was mixed with $200 \mathrm{~mL}$ of concentrated sulfuric acid and heated for 3, 5, 7 and $9 \mathrm{~min}$ in a microwave with medium high power level. The black precipitate collected was then washed with hot distilled water with temperature of $85^{\circ} \mathrm{C}$ until the filtrate was clear enough mainly to remove impurities. Finally, the catalyst was dried in the microwave using medium high power level for $15 \mathrm{~min}$ to remove any moisture content in the catalyst.

\section{CATALYST CHARACTERIZATIONS}

Characteristics of the catalyst were analyzed using several equipment including SEM, FTIR, BET (Kanitkar et al. 2011), TPD- $\mathrm{NH}_{3}$ and XRD. The functional group of the catalyst sample was determined using FTIR (Shimadzu IRTracer-100). Sample of the catalyst was grounded and pelletized using a hydraulic press so that the infrared spectrum in the range of $4000-500 \mathrm{~cm}^{-1}$ can be recorded. The analysis of SEM (JEOL - JSM 6390) was conducted in various magnifications $(500 \times, 1500 \times, 5000 \times$ and $10000 \times)$ mainly to study the morphology of the catalyst. Meanwhile the XRD (Bruker, D8 Advance) was carried out to study the crystallinity of the catalyst with a scan range of $\theta$ from $2^{\circ}$ 
up to $60^{\circ}$ at $4^{\circ} \mathrm{min}^{-1}$ scanning rate. BET (Micromeritics 3 Flex) instrument was used to determine the surface area of the catalyst. The sample of the catalyst was placed in a cell to be degassed at $150^{\circ} \mathrm{C}$ under vacuum for $3 \mathrm{~h}$. Meanwhile, the TPD- $\mathrm{NH}_{3}$ (Micromeritics AutoChem II) was used to identify the density of the acid sites.

\section{ESTERIFICATION OF PFAD}

In esterification process, the raw material, PFAD was esterified with methanol with the presence of the heterogeneous SGAC. Firstly, the PFAD and methanol were weighed based on a molar ratio of 10:1 and $2.5 \mathrm{wt}$. \% of the catalyst was used. Preheated PFAD was firstly poured into the three-neck-round-bottom-flask followed by methanol and catalyst. The solution in the three-neck-round-bottomflask was then refluxed to $70^{\circ} \mathrm{C}$ for about $90 \mathrm{~min}$. Once the reaction was complete, the mixture was poured into a separating funnel to be separated via gravity settling for about $3 \mathrm{~h}$. The biodiesel layer was then collected before being sent for GC-FID analysis.

\section{ANALYSIS OF BIODIESEL}

The biodiesel sample which was prepared with dilution of methanol at a ratio of 0.5:40 (biodiesel: methanol) for the GC-FID analysis (Shimadzu). This analysis was conducted to determine the percentage yield of the biodiesel. Besides, conversion rate was calculated using acid-base titration technique. Approximately $1 \mathrm{~mL}$ of biodiesel were mixed and shaken with $20 \mathrm{~mL}$ of methanol. The mixture was titrated with potassium hydroxide $(\mathrm{KOH})$ solution and the indicator used was phenolphthalein. The titration was complete when a color change occurred. The formula to calculate the yield percentage, acid value and conversion are as 1,2, and 3, respectively (Abreu et al. 2005).

$$
\begin{aligned}
\text { Yield, } \%=\text { Ester content } \times \text { weight of product } \times \\
\text { 100\%/mass of PFAD }
\end{aligned}
$$

$$
\begin{aligned}
\text { Acid value }= & \mathrm{N} \times \mathrm{MW} \mathrm{KOH} \times \text { Volume of } \mathrm{KOH} \\
& \text { used }(\mathrm{mL}) / \text { mass of biodiesel }
\end{aligned}
$$

where $\mathrm{N}$ is the normality of $\mathrm{KOH}$ used; and $\mathrm{MW}$ is the molecular weight of $\mathrm{KOH} ; 56.11 \mathrm{~g} / \mathrm{mol}$

$\begin{aligned} & \text { Percentage of } \\ & \text { conversion } \%\end{aligned}=\begin{gathered}\text { (Acid value of PFAD - Acid value } \\ \text { of biodiesel) } / \text { Acid value of PFAD }\end{gathered}$

\section{RESULTS AND DISCUSSION}

\section{CHARACTERIZATION OF CATALYST}

Figure 1 shows the IR spectra of the unsulfonated ICG catalyst and the sulfonated ICG catalyst after treatment with $\mathrm{H}_{2} \mathrm{SO}_{4}$ for 3, 5, 7 and 9 min in microwave. All 4 samples of sulfonated ICG shows the presence of peak at wave number of 1021.33, 1029.04, 1036.76 and $1013.61 \mathrm{~cm}^{-1}$ for 3, 5, 7 and $9 \mathrm{~min}$, respectively indicating the presence of $\mathrm{SO}_{3}{ }^{-}$asymmetric stretching modes of the $-\mathrm{SO}_{3} \mathrm{H}$ group. The bands at $1682.92,1690.64,1681.96$ and 1680.99 $\mathrm{cm}^{-1}$ for samples of 3, 5, 7 and 9 min of sulfonated ICG are assigned to the $\mathrm{C}=\mathrm{O}$ stretching mode of the $-\mathrm{COOH}$ group. The medium-weak, multiple bands at wave number of $1400-1600 \mathrm{~cm}^{-1}$ shown on the IR spectra of all samples of sulfonated ICG is clearly attributed by the $\mathrm{C}=\mathrm{C}$ stretches in the aromatic ring.

Figure 2 illustrates the XRD diffractogram for all the sulfonated glucose samples. All the 3,5, 7 and 9 min sulfonated glucose catalysts show similar trend of a sharp peak at $2 \theta=2^{\circ}-10^{\circ}$ and one broad peak at $2 \theta=20^{\circ}-30^{\circ}$. Such peaks theoretically are assigned for the amorphous carbon which is composed of the oriented random fashion of aromatic carbon sheets (Zong et al. 2007). This indicates that the samples have high content of non-graphitic carbon structure.

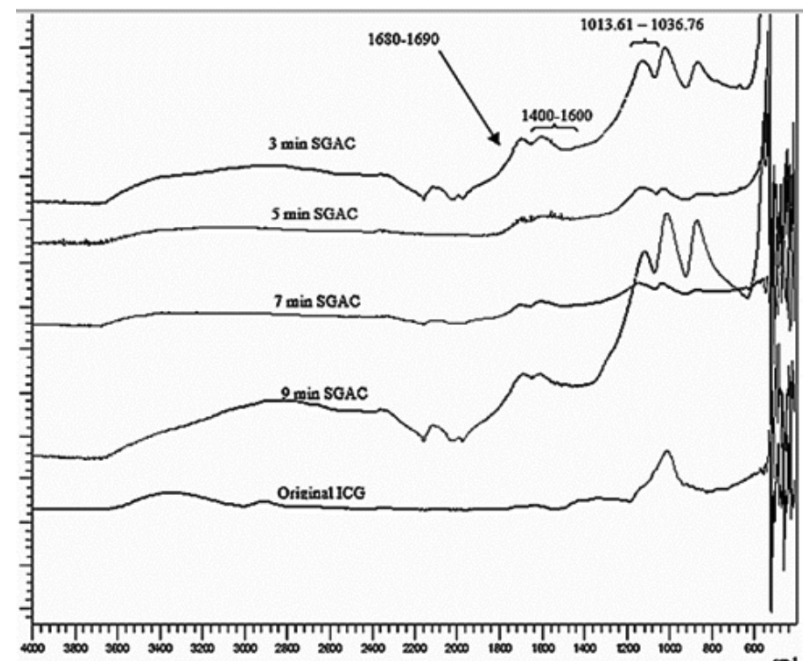

FIGURE 1. IR spectra of ICG sample and 3, 5, 7 and 9 min sulfonated ICG samples 


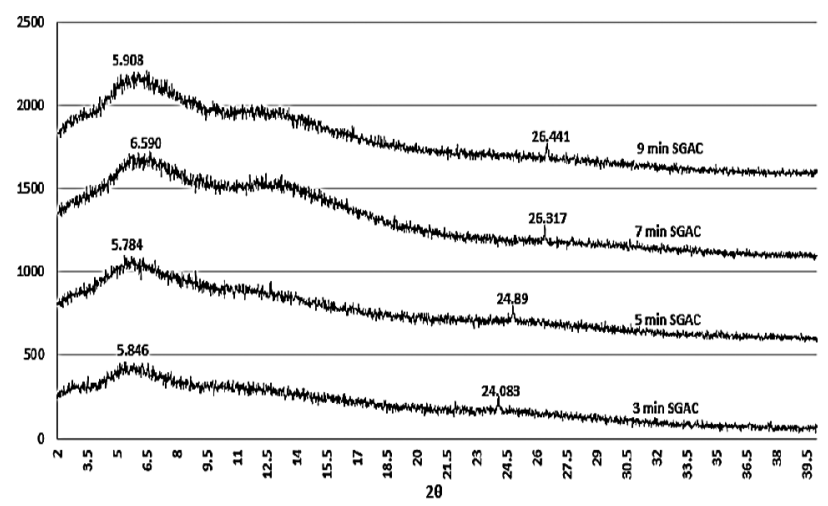

FIGURE 2. Overall XRD diffractogram for 3, 5, 7 and 9 min sulfonated glucose samples

Table 1 presents the BET surface area, pore volume and pore diameter for all the SGAC samples. From the BET analysis, the 3 min SGAC sample has the largest value for both BET surface area and pore volume with $8.02 \mathrm{~m}^{2} / \mathrm{g}$ and $0.004477 \mathrm{~cm}^{3} / \mathrm{g}$. The characteristic of $3 \mathrm{~min}$ SGAC with the largest surface area and highest porosity contributed to its highest catalyst activity among all the SGAC samples. The result is corresponded with the highest percentage yield of biodiesel obtained by using 3 min SGAC in the esterification reaction of PFAD.

Theoretically, larger BET surface area can provide more sites to anchor the active site on the carbon support, enhancing catalytic activity by allowing more reaction to take place at the same time (Lokman et al. 2015). Meanwhile, the pore volume value represents the porosity of the SGAC samples. It should be noticed that 3 min SGAC which produced the highest percentage yield of biodiesel is the most porous catalyst among all the samples. Porosity contributes to the activity of catalyst by offering more active sites for the reactant to attach and react with the catalyst.

Table 1 also shows the density of the acid sites of the catalyst produced. The acid sites density was determined through TPD- $\mathrm{NH}_{3}$. Figure 3 shows all ammonia desorption curves for 3, 5, 7 and 9 min SGAC. The graph observed that the obvious desorption of ammonia occurred at one event which is around $500-850^{\circ} \mathrm{C}$ culminating at $630^{\circ} \mathrm{C}$ for 3 min SGAC. This broad peak at higher temperature proves the presence of strong Brønsted acid sites.
Figure 4 illustrates the morphology of ICG samples after heating with concentrated $\mathrm{H}_{2} \mathrm{SO}_{4}$ for 3, 5, 7 and 9 min. Similar to what had been reported by Lokman et al. (2015) in their study, the SGAC samples showed irregular particle structures. The 3 min SGAC sample exhibited the particle surface to be with the highest degree of surface roughness. Whereas, the SEM image of 5 min SGAC sample shows it has the lowest number of cracks on the catalyst surface and the surface appeared to be smooth. The SEM imaging result corresponds with the BET results for 3 and 5 min SGAC samples whereby the BET surface areas are 8.0210 and $3.6638 \mathrm{~m}^{2} / \mathrm{g}$, respectively.

\section{ANALYSIS OF BIODIESEL}

The biodiesel produced was analysed by using GC-FID to find the percentage yield. Biodiesel yield can be the indicator for the effectiveness of SGAC in esterification of PFAD. The model of the GC used is Shimadzu GC, which is located at N18-02-201-02, Analytical Laboratory, Faculty of Chemical and Energy Engineering, UTM. The results from GC analysis show that the PFAD feedstock contained saturated fatty acids palmitic acid, myristic acid, stearic acid and mono-saturated fatty acid i.e. oleic acid and polyunsaturated linoleic acid.

For the percentage yield of biodiesel, the calculation is based on Equation 4 as follow.

$$
\text { Yield of biodiesel, } \%=\underset{\text { ML } \%+\text { MS } \%}{\sum \text { MP } \%+}
$$

TABLE 1. Effect of sulfonation time on BET surface, pore volume, pore diameter and acid site density

\begin{tabular}{ccccc}
\hline $\begin{array}{c}\text { Type of SGAC } \\
\text { sample }\end{array}$ & $\begin{array}{c}\text { aBET Surface } \\
\text { Area }\left(\mathrm{m}^{2} / \mathrm{g}\right)\end{array}$ & $\begin{array}{c}\text { aPore Volume } \\
\left(\mathrm{cm}^{3} / \mathrm{g}\right)\end{array}$ & $\begin{array}{c}\text { bAcid Site Density } \\
(\mathrm{mmol} / \mathrm{g})\end{array}$ & Yield (\%) \\
\hline $3 \mathrm{~min}$ & 8.0210 & 0.004477 & 3.02283 & 98.23 \\
$5 \mathrm{~min}$ & 3.6638 & 0.001625 & 0.55545 & 96.45 \\
$7 \mathrm{~min}$ & 3.2796 & 0.001382 & 0.48223 & 95.39 \\
$9 \mathrm{~min}$ & 2.7673 & 0.001682 & 0.29779 & 93.50 \\
\hline
\end{tabular}




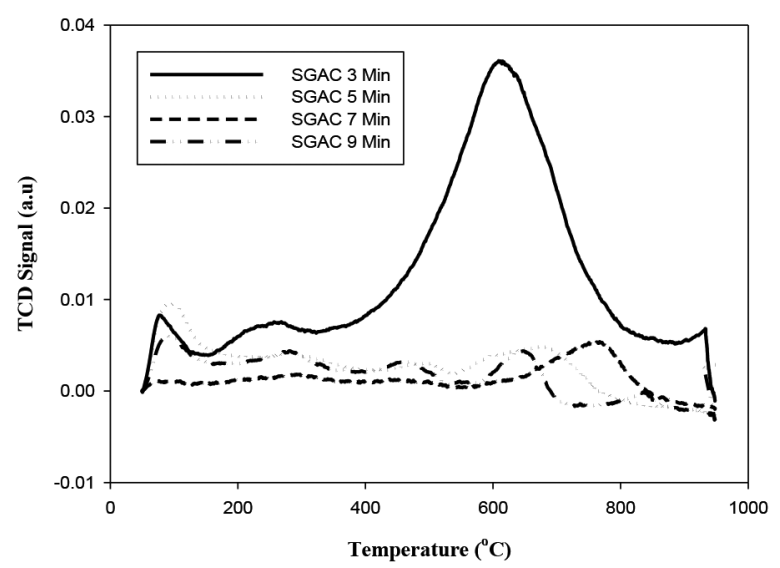

FIGURE 3. Ammonia desorption curves for 3, 5, 7 and 9 min SGAC

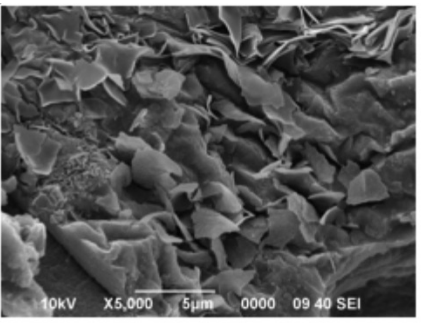

(a)

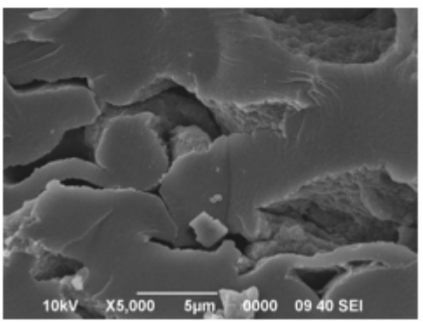

(c)

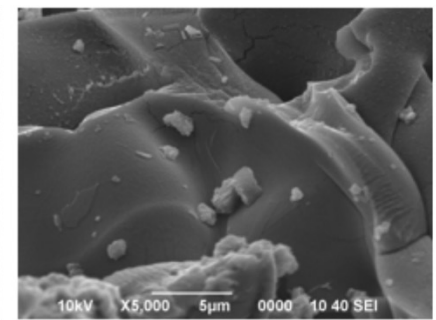

(b)

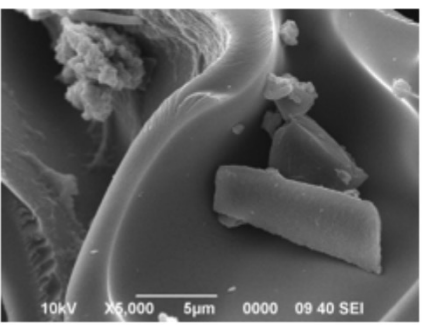

(d)

FIGURE 4. SEM images of 3 min SGAC (a), 5 min SGAC (b), 7 min SGAC (c) and 9 min SGA (d)

The result shows that the 3 min sulfonated glucose catalyst gave the highest percentage yield of biodiesel which is $98.23 \%$ whereas the average percentage yield of all 3, 5, 7 and 9 min sulfonated glucose catalyst is $95.89 \%$. The relatively high yield of biodiesel demonstrates the effectiveness of the catalysts.

Based on Table 2, the 3 min SGAC catalyst sample used in esterification of PFAD had produced the highest percentage yield of biodiesel which signifies that it has the largest BET surface area and the highest pore volume as compared with other SGAC samples. The high porosity of 3 min SGAC sample can help to provide large surface area and site for anchoring the active site on catalyst surface which enhances the catalytic activity. The SEM imaging of 3 min SGAC shows a mesoporous structure and it has the highest degree of surface roughness as compared to other SGAC. The rough surface can provide more sites for reactants to fit into the active site. The increased catalytic activity of the 3 min SGAC was proven by the highest yield of biodiesel obtained from esterification of PFAD.
TABLE 2. Mass and percentage yield of biodiesel produced by esterification of PFAD by sulfonated glucose catalyst

\begin{tabular}{ccc}
\hline $\begin{array}{c}\text { Type of sulfonated } \\
\text { glucose acid catalyst }\end{array}$ & $\begin{array}{c}\text { Mass of biodiesel } \\
\text { produced }(\mathrm{g})\end{array}$ & $\begin{array}{c}\text { Percentage } \\
\text { yield, \% }\end{array}$ \\
\hline 3 min & 25.13 & 98.23 \\
5 min & 24.67 & 96.45 \\
7 min & 24.40 & 95.39 \\
9 min & 23.92 & 93.50 \\
\hline
\end{tabular}

\section{RELATIONSHIP OF THE ACIDITY AND PERFORMANCE OF THE CATALYSTS}

Table 1 shows the properties of all SGAC at different sulfonation time including 3,5,7 and $9 \mathrm{~min}$. The catalytic activity of the catalyst was tested during the esterification process of the PFAD. The results turned out that the lowest time of acid treatment, 3 min SGAC showed the highest percentage yield which reached up to $98.23 \%$. This is due to its larger surface area of $8.021 \mathrm{~m}^{2} / \mathrm{g}$ with highest acid 
site density of $3.02283 \mathrm{mmol} / \mathrm{g}$ compared to the rest of the SGAC. The results showed that a longer acid treatment time reduced the surface area and the total acid site density. The 3 min SGAC exhibited larger surface area and acid site density than previous sulfonated carbohydrate derived catalyst (Lou et al. 2008). Previous study had already proven that all $\mathrm{S}$ atoms in sulfonated catalyst is presented as $-\mathrm{SO}_{3} \mathrm{H}$ groups (Zong et al. 2007). The relativeness of the $-\mathrm{SO}_{3} \mathrm{H}$ groups to be attached to the molecules have much to do with the larger surface area. The larger the surface area, the better chance for the $-\mathrm{SO}_{3} \mathrm{H}$ groups to be anchored to the molecules, thus enhancing the capability of the acid catalyst to esterify the PFAD efficiently.

\section{KINETIC STUDY}

Kinetic study had been carried out to understand the esterification of PFAD by finding the rate constant and activation energy for the reaction. A graph of conversion versus time was plotted to understand the relationship between them. To find the rate constant, a graph of (1-X) versus time was plotted whereby $\mathrm{X}$ is the conversion. The slope of the graph of $\ln (1-\mathrm{X})$ versus time is rate constant, $\mathrm{k}$. Then, the activation energy, $\mathrm{E}_{\mathrm{a}}$ was found by plotting the graph of $\ln \mathrm{k}$ versus $1 / \mathrm{T}$, whereby $\mathrm{k}$ is rate constant and $\mathrm{T}$ is the temperature.

Figure 5 illustrates that the conversion for the esterification reaction at $50^{\circ} \mathrm{C}, 60^{\circ} \mathrm{C}$ and $70^{\circ} \mathrm{C}$ has a decreasing trend as the reaction proceed. This can be explained by the conversion rate of the PFAD that had decreased due to the decreasing amount of unreacted reactant left as the esterification proceed over time.

From Figure 6, the slope of the graph decreases as time increases which indicates that the reaction rate is higher at the beginning of the esterification but decreases in the later stage. The slope of the graph will be the rate constant for the esterification of PFAD whereby the $\mathrm{k}$ values are 0.0124 , 0.0196 and 0.0229 for $50^{\circ} \mathrm{C}, 60^{\circ} \mathrm{C}$ and $70^{\circ} \mathrm{C}$, respectively. Increasing trend was observed whereby the rate constant increases with the increasing esterification temperature.

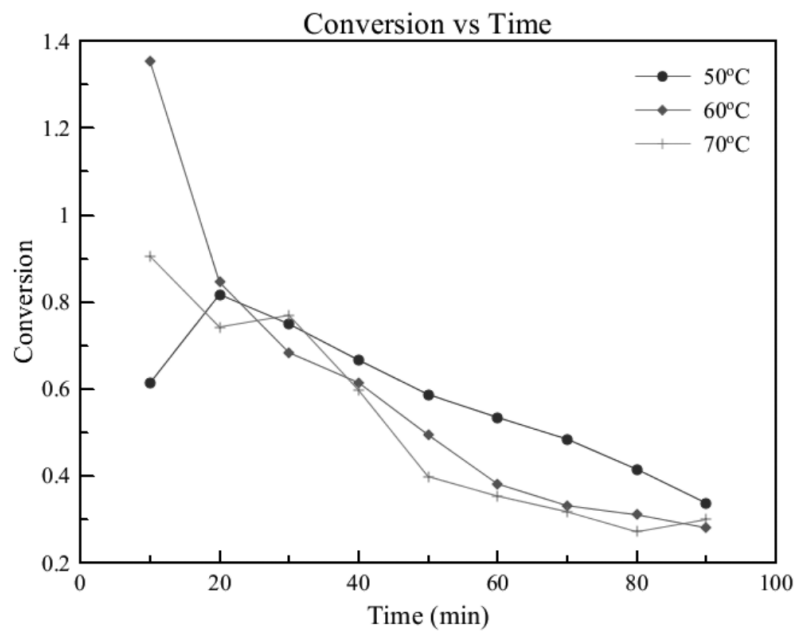

FIGURE 5. Graph of conversion (\%) against time (min)

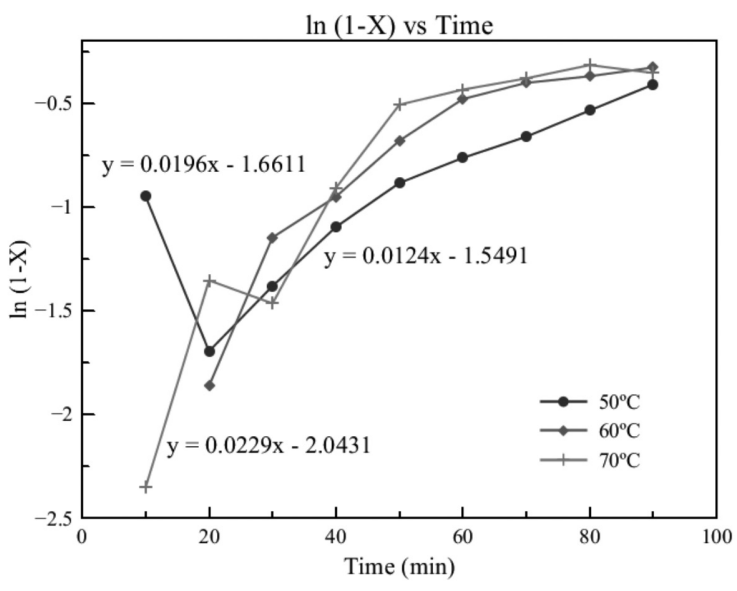

FIGURE 6. Graph of $\ln (1-\mathrm{X})$ against time (min)

Figure 7 illustrates the graph of $\ln \mathrm{k}$ versus $1 / \mathrm{T}$. The $R^{2}$ value of 0.934 is reasonably high which indicates that the esterification reaction of PFAD followed the first order reaction. From the equation below, it is justified that the $-E_{a} / R$ is the slope of the graph.

$$
\ln \mathrm{k}=-\frac{\mathrm{Ea}}{\mathrm{RT}}+\ln \mathrm{A}
$$

The slope obtained from the graph of $\ln \mathrm{k}$ versus $1 / \mathrm{T}$ is -3416.9 . Hence the $-E_{2} / R$ is -3416.9 , where $R$ is the gas constant, $8.314 \mathrm{Jmol}^{-1} \mathrm{~K}^{-1}$

$$
\mathrm{E}_{\mathrm{a}}=3416.9(8.314 / 1000)=28.41 \mathrm{kJmol}^{-1} \mathrm{~K}^{-1} \text {. }
$$

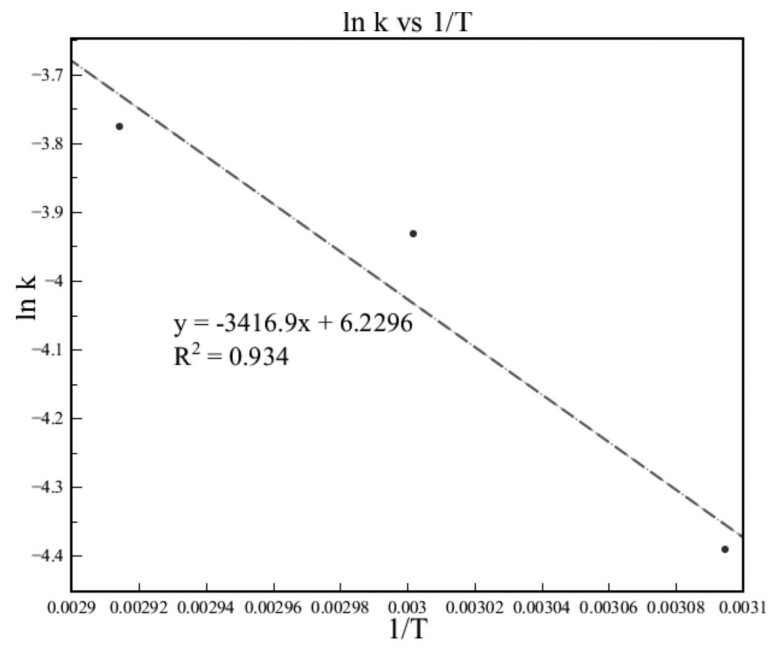

FIGURE 7. Graph of $\ln \mathrm{k}$ against $1 / \mathrm{T}\left(\mathrm{min}^{-1}\right)$

The value of the activation energy for this esterification reaction of PFAD is $28.14 \mathrm{kJmol}^{-1} \mathrm{~K}^{-1}$.

The activation energy was relatively low compared to other previous studies in Ang et al. (2015) and Berrios et 
al. (2007) which had shown the highest activation energy of 50.745 and $40 \mathrm{kJmol}^{-1} \mathrm{~K}^{-1}$, respectively. Smaller value of activation energy will be more favourable in designing a reactor for chemical plant. This is because chemical reactions with higher activation energy exhibit difficulties in control issues due to its rapid increase of the reaction rate as the temperature increases (Luyben 2000).

\section{CONCLUSION}

Microwave assisted sulfonated glucose acid catalyst was successfully synthesized, characterized and tested. Subsequently, kinetic study has been performed to comprehend the nature of the reaction. The use of microwave in preparing the SGAC was found to significantly reduce the time of heating from $12 \mathrm{~h}$ to 15 to $20 \mathrm{~min}$. The SGAC samples then underwent characterization via FTIR, XRD, TPD- $\mathrm{NH}_{3}$, BET and SEM. Positive and encouraging result was obtained from the GC-FID test conducted on the biodiesel produced. The GC-FID analysis on the biodiesel sample revealed that the average percentage yield of biodiesel produced by 3, 5, 7 and 9 min SGAC is $95.89 \%$, which shows the effectiveness of the glucose catalyst. It is also showed that the biodiesel produced contains methyl palmitate (MP), methyl oleate (MO), methyl linoleate (ML), methyl stearate (MS) and methyl myristate (MM) in the decreasing order in terms of composition. The sulfonated glucose acid catalyst (SGAC) has potential as a highly effective and stable heterogeneous acid catalyst for the esterification of high FFAs feedstock which is PFAD with an average yield of $95.89 \%$ of biodiesel.

\section{ACKNOWLEDGEMENTS}

The authors would like to express gratitude and many thanks for the financial support to conduct this study from Ministry of Education and Universiti Teknologi Malaysia under vote no. $07 \mathrm{H} 81$ and $12 \mathrm{~J} 43$.

\section{REFERENCES}

Abreu, F.R., Alves, M.B., Macêdo, C.C.S., Zara, L.F. \& Suarez, P.A.Z. 2005. New multi-phase catalytic systems based on tin compounds active for vegetable oil transesterificaton reaction. Journal of Molecular Catalysis A: Chemical 227(12): 263-267.

Achten, W.M.J., Verchot, L., Franken, Y.J., Mathijs, E., Singh, V.P., Aerts, R. \& Muys, B. 2008. Jatropha bio-diesel production and use. Biomass and Bioenergy 32(12): 10631084.

Ang, G.T., Ooi, S.N., Tan, K.T., Lee, K.T. \& Mohamed, A.R. 2015. Optimization and kinetic studies of sea mango (Cerbera odollam) oil for biodiesel production via supercritical reaction. Energy Conversion and Management 99: 242-251.

Atadashi, I.M., Aroua, M.K., Abdul Aziz, A.R. \& Sulaiman, N.M.N. 2012. Production of biodiesel using high free fatty acid feedstocks. Renewable and Sustainable Energy Reviews 16(5): 3275-3285

Berrios, M., Siles, J., Martín, M.A. \& Martín, A. 2007. A kinetic study of the esterification of free fatty acids (FFA) in sunflower oil. Fuel 86(15): 2383-2388.
Chongkhong, S., Tongurai, C., Chetpattananondh, P. \& Bunyakan, C. 2007. Biodiesel production by esterification of palm fatty acid distillate. Biomass and Bioenergy 31(8): 563-568.

Di Serio, M., Tesser, R., Pengmei, L. \& Santacesaria, E. 2007. Heterogeneous catalysts for biodiesel production. Energy \& Fuels 22(1): 207-217.

Helwani,Z., Othman, M.R.,Aziz, N., Kim, J. \& Fernando, W.J.N. 2009. Solid heterogeneous catalysts for transesterification of triglycerides with methanol: A review. Applied Catalysis A: General 363(1-2): 1-10.

Kanitkar,A., Balasubramanian, S., Lima, M. \& Boldor, D. 2011. A critical comparison of methyl and ethyl esters production from soybean and rice bran oil in the presence of microwaves. Bioresource Technology 102(17): 7896-7902.

Lam, M.K. \& Lee, K.T. 2011. Chapter 15 - Production of biodiesel using palm oil A2 -, In Biofuels, edited by Pandey, A., Larroche, C., Ricke S.C., Dussap, C-G. \& Gnansounou, E. Amsterdam: Academic Press. pp. 353-374.

Lokman, I.M., Rashid, U. \& Taufiq-Yap, Y.H. 2015. Production of biodiesel from palm fatty acid distillate using sulfonatedglucose solid acid catalyst: Characterization and optimization. Chinese Journal of Chemical Engineering 23(11): 1857-1864

Lokman, I.M., Rashid, U., Taufiq-Yap, Y.H. \& Yunus, R. 2015. Methyl ester production from palm fatty acid distillate using sulfonated glucose-derived acid catalyst. Renewable Energy 81: 347-354.

Lou, W.Y., Zong, M.H. \& Duan, Z.Q. 2008. Efficient production of biodiesel from high free fatty acid-containing waste oils using various carbohydrate-derived solid acid catalysts. Bioresource Technology 99(18): 8752-8758.

Luyben, W.L. 2000. Impact of reaction activation energy on plantwide control structures in adiabatic tubular reactor systems. Industrial \& Engineering Chemistry Research 39(7): 2345-2354.

Malaysian Palm Oil Board, M. 2009. Production Technology of Biodiesel from Palm Fatty Acid Distillate (PFAD). http:// palmoilis.mpob.gov.my/publications/TOT/TT-430.pdf (Accessed on Feb, 2017).

Shu, Q., Zhang, Q., Xu, G., Nawaz, Z., Wang, D. \& Wang, J. 2009. Synthesis of biodiesel from cottonseed oil and methanol using a carbon-based solid acid catalyst. Fuel Processing Technology 90(7): 1002-1008.

Zong, M.H., Duan, Z.Q., Lou, W.Y., Smith, T.J. \& Wu, H. 2007. Preparation of a sugar catalyst and its use for highly efficient production of biodiesel. Green Chemistry 9(5): 434-437.

Zong, M.H., Duan, Z.Q., Lou, W.Y., Smith, T.J. \& Wu, H. 2007. Preparation of a sugar catalyst and its use for highly efficient production of biodiesel. Green Chemistry 9(5): 434-437.

Chemical Engineering Department

Faculty of Chemical and Energy Engineering

Universiti Teknologi Malaysia

81310 Skudai, Johor Darul Takzim

Malaysia

*Corresponding author; email: zakiyamani@utm.my

Received: 26 March 2017

Accepted: 9 June 2017 